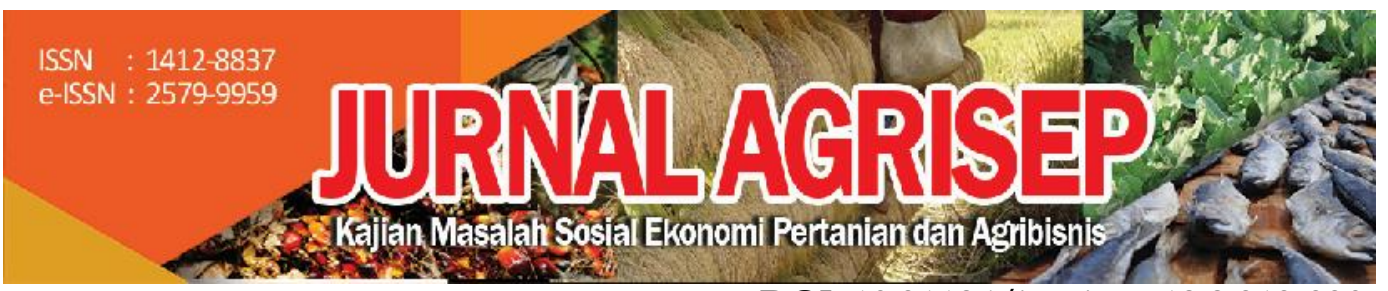

DOI: $10.31186 /$ jagrisep.18.2.313-330

\title{
ANALISIS RISIKO USAHA PEMBENIHAN IKAN NILA MERAH DI KELOMPOK PEMBUDIDAYA IKAN MINO NGREMBOKO KECAMATAN NGEMPLAK KABUPATEN SLEMAN
}

Risk Analysis Of Red Tilapia Breeder In Kelompok Pembudidaya Ikan Mino Ngremboko, Ngemplak Subdistrict Sleman Regency

\author{
Rio Andhika $\square$; Nuning Setyowati; Rr. Aulia Qonita \\ Program Studi Agribisnis Fakultas Pertanian Universitas Sebelas Maret \\ Email: rioandhika015@gmail.com.
}

\begin{abstract}
This study analysed the receipts, costs, and expenses received by red tilapia seed farmers, as well as the level of production risk, price risk and expenditure risk in KPI Mino Ngremboko. The basic method used in this research was a descriptive method. This research was conducted at KPI Mino Ngremboko. The selection of research locations was conducted purposively. The sampling method used was the census method. The analysis was carried out using the coefficient of variation method. Research results there were production risks, price risk, and risk of spending on red tilapia at KPI Mino Ngremboko. The sources of risk that arise were high fish seed mortality rates, increased feed prices, and limited land to increase production. Variation coefficient value (CV) of production risk, price risk, income risk were relatively low that showed the hatchery of red tilapia has a low risk. Meanwhile, the $L$ value of price risk, production risk, and expenditure risk were positive results and the value was greater than BEP. The value shows that when the hatchery reaches the lowest point in production, price, and income, farmers still avoid losses.
\end{abstract}

Keywords : Risk, Red Tilapia Seeds, Mino Ngremboko, Variation Coefficient

\section{ABSTRAK}

Penelitian ini bertujuan untuk mengetahui besarnya penerimaan, biaya, dan pendapatan yang diterima pembudidaya benih ikan nila merah, serta tingkat risiko produksi, risiko harga dan risiko pendapatan pada Kelompok Pembudidaya Ikan (KPI) Mino Ngremboko. Metode dasar yang digunakan dalam penelitian ini adalah metode 
deskriptif. Penelitian ini dilakukan di KPI Mino Ngremboko. Pemilihan lokasi penelitian dilakukan secara sengaja (purposive). Metode pengambilan sampel yang digunakan adalah metode sensus. Analisis yang digunakan metode koefisien variasi. Hasil penelitian menunjukkan bahwa terdapat risiko produksi, risiko harga, dan risiko pendapatan pada pembenihan ikan nila merah di KPI Mino Ngremboko. Sumber risiko yang muncul adalah tingkat kematian benih ikan yang tinggi, harga pakan yang meningkat, dan keterbatasan lahan untuk meningkatkan produksi. Nilai koefisien variasi (CV) dari risiko produksi, risiko harga, risiko pendapatan menunjukkan risiko yang terdapat pada pembenihan ikan nila merah tergolong rendah. Sementara itu nilai $L$ dari risiko harga, risiko produksi, dan risiko pendapatan menunjukkan hasil positif dan nilainya lebih besar dari BEP. Nilai tersebut menunjukkan pada saat usaha pembenihan ikan mencapai titik terendah dalam produksi, harga, dan pendapatan, petani tetap terhindar dari kerugian.

Kata kunci: Risiko, Benih Nila Merah, Koefisien Variasi

\section{PENDAHULUAN}

Permintaan pasar akan produksi perikanan saat ini semakin meningkat yang disebabkan oleh meningkatnya pola konsumsi ikan masyarakat Indonesia. Menurut Badan Pusat Statistik Indonesia (2017), pada tahun 2017 tingkat konsumsi ikan di Indonesia mencapai $46,49 \mathrm{~kg} / \mathrm{kap} / \mathrm{tahun}$. Sementara itu menurut Kementrian Perikanan dan Kelautan (2015), Provinsi Daerah Istimewa Yogyakarta menjadi provinsi dengan perkembangan tingkat konsumsi ikan tertinggi di Indonesia dimana nilai perkembangan tingkat konsumsi ikan mencapai 34,44 \%. Peningkatan konsumsi ikan di Provinsi Daerah Istimewa Yogyakarta mengindikasikan bahwa permintaan terhadap ikan di Provinsi Daerah Istimewa Yogyakarta juga meningkat. Permintaan pasar yang semakin tinggi akan berdampak pada peningkatan produksi ikan budidaya di Provinsi Daerah Istimewa Yogyakarta. Hal ini dapat dilihat dari produksi ikan budidaya yang selalu meningkat tiap tahunnya dari tahun 2011-2015 (Badan Pusat Statistik Provinsi DIY, 2016). Kabupaten Sleman merupakan kabupaten dengan penyumbang produksi ikan terbesar pada tahun 2016 (Badan Pusat Statistik Provinsi DIY, 2017) dengan total produksi $42.376 .160 \mathrm{~kg}$.

Ikan nila merupakan jenis ikan budidaya dengan produksi terbesar di Kabupaten Sleman (Badan Pusat Statistik Sleman, 2016). Produksi ikan nila di Kabupaten Sleman pada tahun 2016 mencapai 171.699,5 Kuintal. Kecamatan Ngemplak merupakan kecamatan dengan produksi ikan nila terbesar dengan menyumbang $17,53 \%$ dari total produksi ikan nila di Kabupaten Sleman dengan total produksi 30.101,60 Kuintal. Hal ini didukung oleh ketersediaan benih yang ada di Kecamatan Ngemplak. Benih ikan merupakan awal dari suatu proses budidaya dan diperlukan suatu jaminan yang menyatakan bahwa kondisi benih suatu ikan sesuai standar benih yang berkualitas ketika akan digunakan dengan jaminan yang tertulis atau bersertifikat (Husen, 2012). Salah satu kelompok pembudidaya benih ikan nila pada Kecamatan Ngemplak adalah Kelompok

314 | Rio Andhika; Nuning Setyowati; Rr. Aulia Qonita; Analisa Resiko Usaha.. 
Pembudidaya Ikan (KPI) Mino Ngremboko. KPI Mino Ngremboko merupakan kelompok pembudidaya ikan yang menghasilkan total produksi benih terbesar di Kecamatan Ngemplak. Berikut adalah data perkembangan produksi benih ikan nila merah pada KPI Mino Ngremboko pada tahun 2014-2016 :

Tabel 1. Jumlah Produksi Benih Ikan Nila Merah Pada KPI Mino Ngremboko

\begin{tabular}{cc}
\hline Tahun & Produksi Benih Ikan Nila Merah (Ekor) \\
\hline 2014 & 48.696 .623 \\
2015 & 51.787 .237 \\
2016 & 60.446 .224 \\
\hline
\end{tabular}

Sumber : KPI Mino Ngremboko, 2017

Berdasarkan Tabel 1, produksi benih ikan nila merah pada KPI Mino Ngremboko tiap tahun terus mengalami kenaikan. Kenaikan terbesar terjadi pada tahun 2016 dengan total produksi benih ikan nila merah sebesar 60.446.224 ekor.

Budidaya benih ikan nila merah merupakan salah satu usaha yang mempunyai prospek yang tinggi. Meskipun terdapat potensi untuk mengmbangkan usaha pembenihan ikan nila merah, namun Kelompok Pembudidaya Ikan Mino Ngremboko tetap perlu memperhitungkan adanya risiko, mengingat sebagian besar usaha pertanian memiliki risiko. Menurut Harwood et al. (1999), sumber-sumber risiko khususnya dalam bidang pertanian terbagi menjadi tiga yaitu risiko produksi, risiko harga, dan risiko pendapatan. Menurut Febby (2018), KPI Mino Ngremboko memiliki kendala internal maupun eksternal seperti dalam hal produksi dan pemasaran. Hal ini kemudian menimbulkan risiko produksi berpengaruh nyata terhadap aktivitas produksi yang kemudian berpengaruh terhadap harga jual benih ikan nila merah yang mengakibatkan risiko pendapatan.

Berdasarkan diskusi di atas, penelitian ini bertujuan untuk menghitung besar penerimaan, biaya dan pendapatan serta menghitung tingkat risiko produksi, risiko harga dan risiko pendapatan pada usaha budidaya ikan nila merah, khususnya KPI Mino Ngremboko. Kelompok budidaya ini merupakan sentra produksi benih ikan nila merah di Kecamatan Ngemplak yang memberikan kontribusi produksi terbesar di Kabupaten Sleman.

\section{METODE PENELITIAN}

Metode dasar yang digunakan dalam penelitian ini adalah deskriptif. Metode penentuan lokasi penelitian adalah secara sengaja (purposive). Penelitian ini dilakukan di di KPI Mino Ngremboko, Ngemplak, Sleman dengan pertimbangan Kecamatan Ngemplak memiliki persentase paling tinggi dalam produksi benih ikan nila. Berikut adalah data produksi benih ikan nila merah di Kabupaten Sleman : 
Tabel 2. Jumlah Produksi Ikan Benih Ikan Nila Merah Kabupaten Sleman, 2016

\begin{tabular}{llcc}
\hline No & & Kecamatan & Produksi Benih (Ekor) \\
\hline 1 & Ngemplak & 324.715 .700 \\
2 & Berbah & 122.001 .700 \\
3 & Mlati & 99.956 .900 \\
4 & Depok & 27.398 .500 \\
5 & Pakem & 9.459 .900 \\
\hline
\end{tabular}

Sumber: Badan Pusat Statistik Sleman, 2017

Metode penentuan sampel yang digunakan adalah metode sensus. Metode sensus adalah metode penarikan sampel dengan semua anggota populasi dijadikan sampel. Jenis sumber data yang digunakan adalah data primer dan data sekunder. Metode pengumpulan data yang dilakukan adalah wawancara, pencatatan, dan observasi.

\section{Metode Analisis Data}

\section{Biaya Total}

Secara matematis menurut Firdaus (2008), dirumuskan sebagi berikut:

$$
T C=F C+V C
$$

dimana TC adalah Total biaya (Rp), FC adalah Jumlah biaya tetap (Rp), dan VC adalah Jumlah biaya variabel (Rp)

\section{Penerimaan}

Menurut (Soekartawi, 2006), dalam menghitung penerimaan digunakan rumus sebagai berikut:

$$
T R=Y \times P_{y}
$$

dimana TR adalah Total penerimaan (Rp), Y adalah Hasil Produksi (ekor), dan Py adalah Harga jual per ekor

\section{Pendapatan}

Menurut Soekartawi (2006), secara matematis dirumuskan sebagai berikut:

$$
P d=T R-T C
$$

dimana Pd adalah Total Pendapatan (Rp), TR adalah Total penerimaan (Rp), dan TC adalah Biaya total (Rp)

316 | Rio Andhika; Nuning Setyowati; Rr. Aulia Qonita; Analisa Resiko Usaha.. 


\section{Risiko Produksi}

Risiko produksi usaha pembenihan ikan nila merah di Kelompok Pembudidaya Ikan Mino Ngremboko dapat diketahui dengan menghitung koefisien variasi.

$$
\mathrm{CV}_{\mathrm{a}}=\frac{\mathrm{V}_{\mathrm{a}}}{\mathrm{E}_{\mathrm{a}}}
$$

dimana CVa adalah Koefisien variasi risiko produksi,Va adalah Simpangan baku produksi (ekor), dan Ea adalah Produksi rata-rata (ekor)

Sebelum mengukur koefisien variasi harus mencari produksi rata-rata pembudidaya pembenihan ikan nila merah dan simpangan bakunya. Secara matematis untuk megetahui risiko dapat dihitung dengan menggunakan ukuran keragaman (variance) maupun simpangan baku (standar deviation). Berikut rumus keragaman untuk menghitung risiko produksi usaha pembenihan ikan nila merah:

$$
\mathrm{V}_{\mathrm{a}}^{2}=\frac{\sum_{\mathrm{i}=1}^{\mathrm{n}}\left(\mathrm{Ei}_{\mathrm{a}}-\mathrm{E}_{\mathrm{a}}\right)^{2}}{\mathrm{n}-1}
$$

dimana Va2 adalah Keragaman produksi, $\sum$ adalah Simbol operasi penjumlahan Eia adalah Produksi yang diterima (ekor), Ea adalah Produksi rata-rata pembudidaya (ekor), $\mathrm{n}$ adalah Jumlah responden dalam penelitian

Adapun rumus simpangan baku yaitu sebagai berikut:

$$
\mathrm{V}_{\mathrm{a}}=\sqrt{\mathrm{V}_{\mathrm{a}}^{2}}
$$

dimana Va adalah Simpangan baku produksi (ekor), dan $V_{a}^{2}$ adalah Keragaman produksi (ekor)

Batas bawah produksi menunjukkan nilai produksi terendah yang mungkin diterima oleh pembudidaya. Rumus batas bawah produksi adalah:

$$
\mathrm{L}_{\mathrm{a}}=\mathrm{E}_{\mathrm{a}}-2 \mathrm{~V}_{\mathrm{a}}
$$

dimana La adalah Batas bawah produksi (ekor), Ea adalah Produksi rata-rata yang diperoleh (ekor), dan Va adalah Simpangan baku produksi (ekor)

Apabila batas bawah produksi (L) dibandingkan dengan titik impas harga (BEP), jika L > BEP maka pembudidaya tetap memperoleh keuntungan pada saat produksi terendah, dan L < BEP artinya pembudidaya harus menanggung kerugian (Hernanto, 1993). Rumus BEP Produksi adalah :

$$
B E P_{\text {produksi }}=\frac{T C}{Y}
$$

dimana TC adalah Total biaya usaha pembenihan ikan nila merah (Rp), Y adalah Harga jual rata-rata benih ikan nila merah 


\section{Risiko Harga}

Risiko harga pada usaha pembenihan ikan nila merah di Kelompok Pembudidaya Ikan Mino Ngremboko dapat diketahui dengan menghitung koefisien variasi.

$$
\mathrm{CV}_{\mathrm{b}}=\frac{\mathrm{V}_{\mathrm{b}}}{\mathrm{E}_{\mathrm{b}}}
$$

Dimana $\mathrm{CVb}$ adalah Koefisien variasi risiko harga, $\mathrm{Vb}$ adalah Simpangan baku harga usaha pembenihan ikan nila merah (Rp), dan Eb adalah Harga rata-rata usaha pembenihan ikan nila merah $(\mathrm{Rp})$

Sebelum mengukur koefisien variasi harus mencari harga rata-rata pembudidaya pembenihan ikan nila merah dan simpangan bakunya. Secara matematis untuk megetahui risiko dapat dihitung dengan menggunakan ukuran keragaman (variance) maupun simpangan baku (standar deviation). Berikut rumus keragaman untuk menghitung risiko harga usaha pembenihan ikan nila merah:

$$
\mathrm{V}_{\mathrm{b}}^{2}=\frac{\sum_{\mathrm{i}=1}^{\mathrm{n}}\left(\mathrm{Ei}_{\mathrm{b}}-\mathrm{E}_{\mathrm{b}}\right)^{2}}{\mathrm{n}-1}
$$

dimana $V_{b}^{2}$ adalah Keragaman harga, $\sum$ adalah Simbol operasi penjumlahan, Eib adalah Harga yang diterima pembudidaya ( $\mathrm{Rp}$ ) Eb adalah Harga rata-rata pembudidaya (Rp), dan $\mathrm{n}$ adalah Jumlah responden dalam penelitian

Adapun rumus simpangan baku yaitu sebagai berikut:

$$
\mathrm{V}_{\mathrm{b}}=\sqrt{\mathrm{V}_{\mathrm{b}}^{2}}
$$

dimana $\mathrm{Vb}$ adalah Simpangan baku harga (Rp), dan $V_{b}^{2}$ adalah Keragaman harga $(\mathrm{Rp})$

Batas bawah harga menunjukkan nilai harga terendah yang mungkin diterima oleh pembudidaya. Rumus batas bawah harga adalah :

$$
\mathrm{L}_{\mathrm{b}}=\mathrm{E}_{\mathrm{b}}-2 \mathrm{~V}_{\mathrm{t}}
$$

Dimana $\mathrm{Lb}$ adalah Batas bawah harga ( $\mathrm{Rp})$, Eb adalah Harga rata-rata yang diperoleh (Rp), dan $\mathrm{Vb}$ adalah Simpangan baku harga (Rp)

Apabila batas bawah harga (L) dibandingkan dengan titik impas harga (BEP), jika L > BEP maka pembudidaya tetap memperoleh keuntungan pada harga jual terendah, dan L < BEP artinya pembudidaya harus menanggung kerugian (Hernanto, 1993). Rumus BEP harga adalah :

$$
B E P_{\text {harg } a}=\frac{T C}{Y}
$$

dimana TC adalah Total biaya usaha (Rp), dan Y adalah Produksi rata-rata (Rp)

318 | Rio Andhika; Nuning Setyowati; Rr. Aulia Qonita; Analisa Resiko Usaha.. 


\section{Risiko Pendapatan}

Risiko pendapatan usaha pembenihan ikan nila merah di Kelompok Pembudidaya Ikan Mino Ngremboko dapat diketahui dengan menghitung koefisien variasi.

$$
\mathrm{CV}_{\mathrm{c}}=\frac{\mathrm{V}_{\mathrm{c}}}{\mathrm{E}_{\mathrm{c}}}
$$

Keterangan: $\mathrm{CV}$ c adalah Koefisien variasi risiko pendapatan, $\mathrm{Vc}_{\mathrm{c}}$ adalah Simpangan baku pendapatan (Rp); dan Ec adalah Pendapatan rata-rata usaha pembenihan ikan nila merah $(\mathrm{Rp})$.

Sebelum mengukur koefisien variasi harus mencari pendapatan rata-rata pembudidaya pembenihan ikan nila merah dan simpangan bakunya. Secara matematis untuk megetahui risiko dapat dihitung dengan menggunakan ukuran keragaman (variance) maupun simpangan baku (standar deviation). Berikut rumus keragaman untuk menghitung risiko pendapatan usaha pembenihan ikan nila merah:

$$
\mathrm{V}_{\mathrm{s}}{ }^{2}=\frac{\sum_{\mathrm{i}=1}^{\mathrm{n}}\left(\mathrm{Ei}_{\mathrm{c}}-\mathrm{E}_{\mathrm{c}}\right)^{2}}{\mathrm{n}-1}
$$

Keterangan: Vc2 adalah keragaman pendapatan; $\sum$ adalah simbol operasi penjumlahan; Eic adalah pendapatan yang diterima pembudidaya (Rp); Ec adalah pendapatan rata-rata pembudidaya (Rp); dan $\mathrm{n}$ adalah jumlah responden dalam penelitian.

Adapun rumus simpangan baku yaitu sebagai berikut:

$$
\mathrm{V}_{\mathrm{c}}=\sqrt{\mathrm{V}_{\mathrm{c}}{ }^{2}}
$$

Keterangan: Vc adalah Simpangan baku pendapatan (Rp); dan Vc2 adalah Keragaman pendapatan (Rp)

Batas bawah pendapatan menunjukkan nilai pendapatan terendah yang mungkin diterima oleh pembudidaya. Apabila nilai batas bawah pendapatan ini lebih dari nol, maka pembudidaya tidak akan pernah mengalami kerugian. Sebaliknya jika nilai batas bawah pendapatan kurang dari nol dapat disimpulkan bahwa setiap usaha pembenihan ikan nila merah ada peluang kerugian yang akan diderita oleh pembudidaya. Rumus batas bawah pendapatan adalah :

$$
\mathrm{L}_{\mathrm{c}}=\mathrm{E}_{\mathrm{c}}-2 \mathrm{~V}_{\mathrm{c}}
$$

Keterangan: Lc adalah Batas bawah pendapatan (Rp); Ec adalah Pendapatan rata-rata yang diperoleh (Rp); dan Vc adalah Simpangan baku pendapatan (Rp)

Apabila nilai $\mathrm{CV} \leq 0,5$ atau $\mathrm{L}>0$ menyatakan bahwa pembudidaya akan selalu terhindar dari kerugian dan nilai $\mathrm{CV}>0,5$ atau $\mathrm{L}<0$ berarti ada peluang kerugian yang akan ditanggung oleh pembudidaya (Hernanto,1993). 


\section{HASIL DAN PEMBAHASAN}

\section{Karakteristik Pembudidaya}

Karakteristik Pembudidaya merupakan gambaran umum tentang keadaan latar belakang responden yang dapat berpengaruh terhadap usahanya. Responden penelitian ini adalah pembudidaya benih ikan nila merah di Kelompok Pembudidaya Ikan (KPI) Mino Ngremboko Kecamatan Ngemplak Kabupaten Sleman yang berjumlah 34 orang dengan kriteria responden melakukan pembenihan minimal selama 1 periode budidaya. Berikut adalah gambaran karakteristik pembudidaya di KPI Mino Ngremboko :

Tabel 3. Karakteristik Pembudidaya

\begin{tabular}{ll}
\hline \multicolumn{1}{c}{ Kategori } & \multicolumn{1}{c}{ Karakteristiik } \\
\hline Kelompok Umur & $15-64$ tahun \\
Tingkat Pendidikan & Tamat SMA \\
Pengalaman Usaha & $6-10$ tahun \\
Luas Kolam & $2600-4100$ \\
Anggota Keluarga & $3-4$ orang \\
\hline
\end{tabular}

Sumber: Analisis Data Primer, 2018

Tabel 3 menginformasikan berbagai macam karateristik pembudidaya. Mayoritas pembudidaya berada di kelompok umur 15-64 tahun yang tergolong usia produktif dengan tingkat pendidikan tamat SMA. Mayoritas pembudidaya memiliki pengalaman usaha budidaya sebanyak 6-10 tahun. Jumlah luas kolam yang dimiliki sebesar 2600-4100 $\mathrm{m}^{2}$ dengan jumlah anggota keluarga sebanyak 3-4 orang.

\section{Pengukuran Biaya Total, Penerimaan, dan Pendapatan Budidaya Pembenihan Ikan Nila Merah}

Konsep biaya budidaya pembenihan ikan nila merah yang digunakan di KPI Mino Ngremboko adalah konsep biaya variabel dan biaya tetap yang terdiri atas biaya sarana produksi, biaya penyusutan dan biaya lain-lain. Berikut adalah biaya yang dikeluarkan oleh pembudidaya :

1. Biaya sarana produksi terdiri dari biaya indukan, biaya pakan induk dan benih, biaya vitamin, dan biaya kapur.

2. Biaya tenaga kerja yaitu biaya yang dikeluarkan pembudidaya kepada sejumlah tenaga kerja yang dipekerjakan selama satu periode pembenihan ikan nila merah.

3. Biaya lain-lain yaitu biaya sewa kolam, pajak tanah, biaya panen, dan biaya dana taktis.

4. Biaya penyusutan yaitu biaya yang dikeluarkan oleh pembudidaya atas perhitungan biaya aset selama masa pakai antara lain biaya peralatan seperti ember, skop net, cangkul, drum, dan hapa.

320 | Rio Andhika; Nuning Setyowati; Rr. Aulia Qonita; Analisa Resiko Usaha.. 
Biaya total merupakan keseluruhan uang yang dikeluarkan pembudidaya untuk melakukan kegiatan produksi yang meliputi biaya tetap dan biaya variable (Firdaus, 2008). Biaya tetap dalam usaha pembenihan ikan nila merah meliputi biaya sewa kolam, pajak tanah, biaya tenaga kerja dan biaya penyusutan. Biaya variabel dalam usaha pembenihan ikan nila merah meliputi biaya sarana produksi, biaya potongan panen dan biaya dana taktis. Menurut Suratiyah (2015) dalam operasi usahatani, petani akan menerima penerimaan dan pendapatan usahataninya. Pendapatan merupakan hasil dari selisih dari penerimaan dengan biaya total. Penerimaan merupakan hasil kali produksi total benih ikan nila merah dengan harga produk ikan nila merah sesuai dengan ukurannya Berikut merupakan biaya total, rata-rata penerimaan dan pendapatan pada pembenihan ikan nila merah di KPI Mino Ngemboko :

Tabel 4. Biaya Total Pembenihan Ikan Nila Merah di Kelompok Pembudidaya Ikan Mino Ngremboko, Ngemplak, Sleman Tahun 2018

\begin{tabular}{llcc}
\hline No. & \multicolumn{1}{c}{ Uraian } & Rata-Rata Jumlah Biaya & Persentase (\%) \\
\hline 1. & Biaya Tetap & 55.279 & \\
a. Sewa kolam & 85.435 & 0.4 \\
b. Biaya Penyusutan & 37.906 & 0.6 \\
c. Pajak Tanah & $\mathbf{1 7 8 . 6 2 0}$ & 0.3 \\
& & $\mathbf{1 . 3}$ \\
Total Biaya Tetap & & \\
Biaya Variabel & 8.063 .977 & 55.3 \\
a. Biaya Sarana & 2.012 .962 & 13.8 \\
Produksi & 979.551 & 6.7 \\
b. Potongan Panen & 3.341 .176 & 22.9 \\
c. Dana Taktis & $\mathbf{1 4 . 3 9 7 . 6 6 8}$ & 98.7 \\
d. Biaya Tenaga Kerja & & $\mathbf{1 0 0 . 0}$ \\
Total Biaya Variabel & $\mathbf{1 4 . 5 7 6 . 2 8 8}$ & \\
\hline
\end{tabular}

Sumber : Analisis Data Primer, 2018

Tabel 5. Rata-rata Penerimaan Pembenihan Ikan Nila Merah di Kelompok Pembudidaya Ikan Mino Ngremboko, Ngemplak, Sleman Tahun 2018

\begin{tabular}{llccc}
\hline No. & \multicolumn{1}{c}{ Uraian } & Produksi Benih & $\begin{array}{c}\text { Harga Jual } \\
\text { per unit }\end{array}$ & $\begin{array}{c}\text { Penerimaan/ } \\
\text { siklus (Rp) }\end{array}$ \\
\hline 1. & $\begin{array}{l}\text { Produksi Benih Ikan } \\
\text { (ekor) }\end{array}$ & 489.775 & 41.99 & 20.327 .827 \\
2. & $\begin{array}{l}\text { Penjualan Induk } \\
\text { Ikan(kg) }\end{array}$ & 14,19 & 22.000 & 248.859 \\
\hline \multicolumn{4}{c}{ Jumlah } \\
\hline
\end{tabular}

Sumber : Analisis Data Primer, 2018 
Tabel 6. Rata-rata Pendapatan Pembenihan Ikan Nila Merah di Kelompok Pembudidaya Ikan Mino Ngremboko, Ngemplak, Sleman Tahun 2018

\begin{tabular}{clc}
\hline No. & \multicolumn{1}{c}{ Uraian } & Rata-rata Biaya/Siklus (Rp) \\
\hline 1. & Total Penerimaan & Rp. $20.817 .602,00$ \\
2. & Total Biaya & Rp. $14.576 .288,00$ \\
3. & Total Pendapatan & Rp.6.241.315,00 \\
\hline
\end{tabular}

Sumber : Analisis Data Primer, 2018

\section{Identifikasi Sumber-sumber Risiko Pembenihan Ikan Nila Merah}

Pembudidaya dalam menjalankan pembenihan ikan nila merah tentunya tidak terlepas dari berbagai permasalahan. Pembudidaya selalu menghadapi risiko di dalam usahanya, terutama karena kebanyakan hasil pertanian masih bergantung pada musim dan cuaca seperti di negara-negara lain India (Kumar dan Singh, 2017), Thailand (Aditto, 2011), Estonia (Laanemets, 2011) termasuk juga pembenihan ikan nila merah masih bergantung dengan alam. Beberapa sumber risiko yang terjadi saling berhubungan dan tidak bisa dipisah satu sama lain. Risiko produksi akan menyebabkan produksi yang dihasilkan menjadi menurun secara kualitas. Hal ini akan berpengaruh terhadap pendapatan pembudidaya. Berikut adalah sumber-sumber resiko utama berdasarkan pengalaman pembudidaya dan pengamatan di KPI Mino Ngremboko :

\section{Risiko Produksi}

a. Musim / Cuaca

Ikan nila merah membutuhkan suhu yang optimal dalam bertahan hidup. Ketika suhu air terlalu dingin, nafsu makan benih ikan nila merah akan berkurang sehingga nutrisi yang masuk menjadi berkurang. Hal ini juga berlaku ketika suhu terlalu panas tubuh ikan juga tidak dapat mencerna makanan dengan baik. Selain berhubungan dengan nafsu makan, ketersediaan air ketika musim kemarau menjadi berkurang yang akan menyebabkan produksi benih ikan nila merah menurun karena air menjadi komponen utama dalam pembenihan ikan nila merah.

b. Hama dan Penyakit

a). Burung.

Predator utama bagi benih ikan nila merah. Serangan burung banyak terjadi pada siang dan sore hari.

322 | Rio Andhika; Nuning Setyowati; Rr. Aulia Qonita; Analisa Resiko Usaha.. 
b) Notonecta.

Hama ini berbentuk kecil berwarna putih menyerupai beras. Hama ini akan menyengat benih ikan nila merah, dan banyak menyebabkan kematian pada benih ikan nila merah.

c) Jamur

Penyakit ini menyerang organ-organ luar pada benih ikan nila merah seperti sirip, kulit, mulut atau insang

\section{Risiko Harga}

Permasalahan di KPI Mino Ngremboko yang menimbulkan risiko harga, adalah harga jual pakan benih ikan nila merah yang selalu meningkat. Pakan yang digunakan oleh para pembudidaya adalah Pokphand 781. Pokphand 781 adalah merek pakan ikan yang bermitra dengan KPI Mino Ngremboko dalam hal pakan benih ikan nila merah. Artinya semua pakan yang digunakan oleh sebagian besar pembudidaya adalah Pokphand 781.

\section{Risiko Pendapatan}

Fluktuasi harga yang berisiko pada harga komoditas pertanian sertabesarnya pembiayaan menjadikan risiko tersediri terhadap pendapatan yang diharapkan petani (Nicholson, 1995).Tingkat pendapatan yang diperoleh pembenihan ikan nila merah di KPI Mino Ngremboko mengalami fluktuasi pada setiap periode dikarenakan fluktuasi jumlah produksi yang dihasilkan pembudidaya. Hasil produksi benih ikan nila merah di KPI Mino Ngremboko ditentukan oleh tingkat mortalitas pada setiap periode produksi. Selain itu biaya produksi yang dikeluarkan oleh pembudidaya juga berpengaruh terhadap tingkat pendapatan. Penambahan luas kolam akan meningkatkan produksi benih ikan nila merah. Namun terbatasnya lahan dalam pembuatan kolam baru menjadi kendala dalam hal meningkatkan produksi dengan menambah jumlah luas kolam.

\section{Analisis Risiko Pembenihan Ikan Nila Merah}

\section{Risiko Produksi}

Pembudidaya dalam melakukan pembenihan ikan nila merah selalu mengharapkan produksi yang tidak merugikan dan dapat menutup biaya pembenihan. Jumlah produksi dipengaruhi oleh jumlah dan kualitas input yang digunakan dalam pembenihan. Dalam budidaya pertanian, hasil yang diperoleh dapat lebih kecil dari hasil yang diperhitungkan sehingga dapat menyebabkan kerugian bagi petani (Simanjuntak, 2013). Munculnya risiko produksi yang diakibatkan penyimpangan jumlah produksi dari yang diharapkan sehingga terdapat 
variasi jumlah produksi dan akan mempengaruhi keputusan dalam melakukan pembenihan ikan nila merah. Berikut perhitungan risiko produksi risiko produksi pada KPI Mino Ngremboko :

Tabel 7. Risiko Produksi Ikan Nila Merah

\begin{tabular}{lr}
\hline \multicolumn{1}{c}{ Keterangan } & Jumlah \\
\hline Jumlah Produksi (Ekor) & 16.652 .363 \\
Produksi Tertinggi (Ekor) & 966.000 \\
Produksi Terendah (Ekor) & 127.280 \\
Rata-Rata Produksi (Ekor) & 489.775 \\
Nilai Varians (V2) & 52.198 .439 .420 \\
Standar Deviasi (V) & 228.470 \\
Koefisien Variasi (CV) & 0,47 \\
Batas Bawah Produksi (L) & 32.835 \\
BEP (Ekor) & 347.137 \\
\hline
\end{tabular}

Sumber : Analisis Data Primer, 2018

Nilai KV yaitu 0,47 $\leq 0,5$ dapat diartikan bahwa dari segi produksi benih ikan nila merah mempunyai tingkat risiko yang rendah. Batas bawah produksi bernilai positif yaitu sebesar 32.835 yang artinya perkiraan produksi terendah dalam satu siklus budidaya adalah 32.835 ekor. Namun apabila batas bawah produksi dibandingkan dengan titik impas produksi (BEP), maka dapat diartikan apabila budidaya benih ikan nila merah yang dilakukan pembudidaya mencapai batas produksi terendah, pembudidaya harus menanggung kerugian sebesar 314.302 ekor.

\section{Risiko Harga}

Harga mempunyai pengaruh langsung pada jumlah penerimaan yang diterima oleh pembudidaya, sehingga apabila harga jual benih ikan nila merah di tingkat pembudidaya jatuh maka akan berpengaruh pada menurunnya penerimaan pembudidaya. Menurut Sofyan (2004) Harga pertanian cenderung berubah dan tidak memiliki kestabian serta tidak adanya kepastian. Perbedaan harga jual benih nila merah yang diterima pembudidaya menyebabkan adanya variasi harga jual yang kemudian memunculkan risiko harga. Perubahan harga yang tidak pasti di masa depan menimbulkan adanya risiko harga yang dapat merubah keputusan pembudidaya dalam melakukan pembenihan ikan nila 
merah. Berikut perhitungan risiko harga benih ikan nila merah di KPI Mino Ngremboko :

Tabel 8. Risiko Harga Pembenihan Ikan Nila Merah

\begin{tabular}{lr}
\hline \multicolumn{1}{c}{ Keterangan } & Jumlah \\
\hline Harga Tertinggi (Rp/ekor) & 43,28 \\
Harga Terendah (Rp/ekor) & 40,24 \\
Harga Rata-Rata (Rp/ekor) & 41,99 \\
Nilai Varians (V2) & 0,6 \\
Standar Deviasi (V) & 0,78 \\
Koefisien Variasi (CV) & 0,02 \\
Batas Bawah Harga (L) & 40,44 \\
BEP (Ekor) & 29,76 \\
\hline
\end{tabular}

Sumber : Analisis Data Primer, 2018

Nilai KV yaitu 0,02 $\leq$ 0,5 dapat diartikan bahwa dari segi harga benih ikan nila merah mempunyai risiko rendah. Batas bawah harga jual benih ikan nila merah bernilai positif yaitu sebesar Rp.40,44/ ekor yang artinya kemungkinan harga jual benih ikan nila merah di tingkat pasar paling rendah yaitu Rp.40,44/ekor. Berdasakan titik impas harga, nilai batas bawah harga masih berada di atas titik impasnya yaitu $\mathrm{L}=40,44 \geq$ $\mathrm{BEP}=29,76$. Artinya, meskipun harga benih ikan nila merah yang diterima pembudidaya mencapai titik terendah yaitu Rp. 40,44/ekor, pembudidaya masih tetap memperoleh pendapatan sebesar Rp. 10,68/ekor. Hasil analisa juga menunjukkan bahwa untuk mencapai titik impas, pembudidaya hanya harus menjual benih ikan nila merah dengan harga Rp. 29,76/ekor.

\section{Risiko Pendapatan}

Tujuan pembudidaya dalam melakukan kegiatan pembenihan ikan nila merah adalah untuk memperoleh pendapatan (Sunaryo, 2009). Pendapatan yang maksimal dapat diperoleh apabila penerimaan pembudidaya tinggi dan biaya mengusahakan rendah. Terdapat beberapa faktor yang mengakibatkan penerimaan yang diterima oleh pembudidaya berbeda-beda, antara lain jumlah populasi benih ikan nila merah, penggunaan sarana produksi, tenaga kerja dan lain-lain. Hal tersebut menyebabkan pendapatan pembudidaya juga berbeda-beda. Perbedaan pendapatan yang diterima pembudidaya itulah yang menyebabkan adanya variasi pendapatan yang kemudian memunculkan adanya risiko. Berikut perhitungan risiko pendapatan pembenihan ikan nila merah di KPI Mino Ngremboko : 
Tabel 9. Risiko Pendapatan Pembenihan Ikan Nila Merah

\begin{tabular}{lr}
\hline \multicolumn{1}{c}{ Keterangan } & \multicolumn{1}{c}{ Jumlah } \\
\hline Jumlah Pendapatan (Rp) & $212.204 .719,00$ \\
Pendapatan Tertinggi (Rp) & $13.667 .104,00$ \\
Pendapatan Terendah (Rp) & $664.056,00$ \\
Rata-Rata Pendapatan (Rp) & $6.241 .315,00$ \\
Nilai Varians (V $)$ & $9.736 .892 .534 .953,00$ \\
Standar Deviasi (V) & $3.120 .399,00$ \\
Koefisien Variasi (CV) & 0,5 \\
Batas Bawah Pendapatan (L) & Rp. 516 \\
\hline
\end{tabular}

Sumber : Analisis Data Primer, 2018

Nilai $C V \leq 0,5$ dapat diartikan bahwa dari segi pendapatan pembenihan ikan nila merah mempunyai risiko rendah dengan batas bawah pendapatan bernilai positif yaitu sebesar Rp 516. Artinya yaitu pendapatan terendah dalam melakukan usaha pembenihan nila merah adalah Rp 516.

\section{Upaya Penanggulangan Risiko Pembenihan Ikan Nila Merah}

Pembudidaya dalam menjalankan usahanya selalu menghadapi risiko. Risiko yang paling sering dirasakan oleh pembudidaya adalah mengenai kondisi iklim. Komponen utama dalam usaha pembenihan ikan nila merah adalah sumber daya air. Oleh karena itu, kondisi musim sangat berpengaruh terhadap pendapatan usaha pembudidaya. Hal terpenting agar suatu usaha terhindar dari kerugian, yakni dengan melakukan tindakan pencegahan kerugian yang dilaksanakan selama masa usaha, baik itu dilakukan, sebelum kejadian, ataupun setelah kejadian (Darmawi 2005). Berdasarkan pengamatan dan wawancara, berikut adalah upaya penanggulangan yang dilakukan pembudidaya benih ikan nila merah di KPI Mino Ngremboko :

\section{Risiko Produksi}

a) Mengatur waktu makan ikan pada kondisi yang sesuai dengan benih ikan nila merah

b) Pemakaian alat pengukur suhu dan $\mathrm{pH}$ di dalam kolam.

c) Mengoptimalkan kolam ketika musim kemarau

d) Memberikan perawatan khusus pada kolam-kolam budidaya.

e) Menggunakan obat-obatan serta alat-alat untuk menanggulangi hama dan penyakit

f) KPI Mino Ngremboko memfasilitasi pembudidaya dalam hal pembelian obat-obatan.

326 | Rio Andhika; Nuning Setyowati; Rr. Aulia Qonita; Analisa Resiko Usaha.. 


\section{Risiko Harga}

a) Mencampurkan pakan lain untuk menekan harga merek pakan yang yang terus meningkat

b) KPI Mino Ngremboko menyediakan merek pakan lain yang dapat diberikan kepada pembudidaya benih ikan nila merah.

\section{Risiko Pendapatan}

a) Pengembangan Micro Bubble Generator (MBG) untuk meningkatkan produksi benih ikan nila merah.

b) Melakukan pengkajian dan pengawasan penggunaan micro bubble generator terhadap budidaya benih ikan nila merah.

Berdasarkan hasil penelitian menunjukkan bahwa usaha pembenihan ikan nila merah di KPI Mino Ngremboko mempunyai prospek yang tinggi. Hal ini dapat dilihat dari tingkat pendapatan pembudidaya benih ikan nila merah yang cukup besar. Namun disamping itu, usaha pembenihan benih ikan nila merah di KPI Mino Ngremboko terdapat risiko antara lain risiko produksi, risiko harga dan risiko pendapatan. Sumber risiko yang muncul adalah tingkat kematian benih ikan yang tinggi, harga pakan yang meningkat, dan keterbatasan lahan untuk meningkatkan produksi. Beberapa upaya telah dilakukan pembudidaya benih ikan nila merah untuk mengurangi risiko-risiko yang dihadapi. Namun upaya tersebut belum sepenuhnya efektif, pengaruh risiko-risiko tersebut masih cukup signifikan terhadap budidaya benih ikan nila merah di KPI Mino Ngremboko. Oleh karena itu pembudidaya maupun KPI Mino Ngremboko diharapkan untuk lebih memperhatikan budidaya benih ikan nila merah seperti penerapan teknologi di dalam budidaya, serta menyesuaikan harga jual benih di pasaran. Kedua hal ini diharapkan mampu untuk meningkatkan produksi sehingga meningkatkan pendapatan pembudidaya di KPI Mino Ngremboko.

\section{SIMPULAN DAN SARAN}

\section{Simpulan}

Berdasarkan hasil pembahasan dapat diambil kesimpulan sebagai berikut: 1. Rata-rata besarnya penerimaan pembenihan ikan nila merah di Kelompok Pembudidaya Ikan Mino Ngremboko selama satu siklus pembenihan adalah Rp. 20.817.602,00, sementara itu rata-rata biaya yang dikeluarkan adalah Rp. 14.576.288,00 dan rata-rata pendapatan yang diperoleh sebesar Rp Rp.6.241.315,00. Biaya yang dikeluarkan oleh pembudidaya dalam satu siklus pembenihan ikan nila merah adalah biaya sarana produksi, biaya tenaga kerja, biaya penyusutan dan biaya lain-lain. 
3. Sumber risiko yang timbul pada pembenihan ikan nila merah adalah risiko produksi, risiko harga dan risiko pendapatan.

a) Risiko produksi yang harus dihadapi antara lain tingkat kematian benih ikan nila merah yang tinggi yang disebabkan oleh musim dan juga hama penyakit. Risiko produksi pembenihan ikan nila merah pada KPI Mino Ngremboko tergolong rendah. Produksi terendah benih ikan nila merah adalah 32.835 ekor. Pembudidaya harus bisa menanggung kerugian sebesar 314.302 ekor pada saat mencapai titik produksi terendah (L).

b) Risiko harga yang harus dihadapi adalah harga pakan meningkat dan harga jual fluktuatif. Risiko harga pada pembenihan ikan nila merah pada KPI Mino Ngremboko tergolong rendah. Harga jual terendah benih ikan nila merah adalah Rp. 40,44. Titik Impas Harga sebesar Rp 29,76 artinya pembudidaya tetap terhindar dari kerugian pada saat harga jual mencapai batas terendah (L).

c) Risiko pendapatan yang dihadapi adalah keterbatasan lahan untuk meningkatkan produksi. Risiko pendapatan pembenihan ikan nila merah pada KPI Mino Ngremboko tergolong rendah. Nilai L risiko pendapatan sebesar Rp. 516, artinya pendapatan terendah dalam melakukan usaha pembenihan ikan nila merah sebesar Rp. 516.

4. Upaya penanggulangan yang dilakukan pembudidaya terhadap risiko produksi, risiko harga, dan risiko pendapatan antara lain :

a) Risiko Produksi : mengatur jam pemberian pakan ikan, mengurangi jumlah produksi benih ikan nila merah serta mengoptimalkan kolam lain yang memiliki sumber daya air melimpah pada saat musim kemarau, menggunakan obat-obatan untuk menanggulangi hama dan penyakit

b) Risiko harga: mencampurkan pakan lain untuk mensiasati meningkatnya harga pakan,

c) Risiko pendapatan: micro bubble generator untuk meningkatkan jumlah produksi benih ikan nila merah.

\section{Saran} lain:

Berdasarkan hasil pembahasan, maka saran yang dapat diberikan antara

1. Kelompok Pembudidaya Ikan (KPI) Mino Ngremboko sebaiknya menyediakan alternatif lain dalam hal merek pakan dengan cara bermitra dengan perusahaan pakan, serta memberikan penyuluhan kepada pembudidaya benih ikan nila merah terkait nutrisi pakan benih dan juga alternatif untuk membuat pakan benih secara mandiri.

328 | Rio Andhika; Nuning Setyowati; Rr. Aulia Qonita; Analisa Resiko Usaha.. 
2. Kelompok Pembudidaya Ikan (KPI) Mino Ngremboko sebaiknya berkoordinasi harga jual benih ikan nila merah kepada kelompok pembesar ikan nila merah agar harga jual benih ikan nila merah dapat meningkat.

3. Pembudidaya benih ikan nila merah sebaiknya menggunakan alat pengukur suhu dan $\mathrm{pH}$ dalam mengukur suhu dan $\mathrm{pH}$ di dalam air

4. Kelompok Pembudidaya Ikan (KPI) Mino Ngremboko tetap melanjutkan proyek micro bubble generator pada benih ikan nila merah untuk meningkatkan produksi dengan cara meneruskan mitra dengan universitas dan juga dinas perikanan yang mampu menaungi projek micro bubble generator.

\section{DAFTAR PUSTAKA}

Aditto, S. 2011. Risk Analysis Of Smallholder Farmers In Central And North-East Thailand. Lincoln University Digital Thesis

Badan Pusat Statistik Daerah Istimewa Yogyakarta 2017. Statistik Daerah Daerah Istimewa Yogyakarta 2017. Badan Pusat Statistika Daerah istimewa Yogyakarta: Yogyakarta.

Badan Pusat Statistik Indonesia. 2017. Konsumsi Ikan Per Tahun. https://bps.go.id/. Diakses pada 4 Juni 2018

Badan Pusat Statistik Sleman. 2017. Kabupaten Sleman Dalam Angka 2017. Badan Pusat Statistika Kabupaten Sleman. Yogyakarta.

Darmawi, H. 2014. Manajemen Perbankan. Jakarta: PT. Bumi Aksara.

Ekonomi UI

Firdaus, M. 2008. Manajemen Agribisnis. Jakarta: Bumi Aksara

Harwood, J., R. Heifner, K. Coble, J. Perry, dan S. Agapi. 1999. Managing Risk in Farming Concepts, Research, and Analysis. Agricultural Economic Report no. 774. US Department of Agriculture

Hernanto, F. 1993. Ilmu Usahatani. Jakarta : Penerbit Swadaya

Kecamatan Pamijahan Kabupaten Bogor. Bogor: Departemen

Kumar, A. dan R. Singh. 2017. Risk Analysis in Sugarcane Production: Evidences from Uttar Pradesh and Maharashtra States of India. International Journal of Current Microbiology and Applied Sciences ISSN: 2319-7706 Volume 6 Number 9 (2017) pp. 1211-1216

Laanemets. 2011. Price, Yield, and Revenue Risk in Wheat Production in Estonia. Agronomy Research 9 (Special Issue II), 421-426, 2011 
Lestari, F.R. 2018. Strategi Pemasaran Ikan Nila Merah Pada Koperasi Mina Ngremboko di Kecamatan Ngemplak Kabupaten Sleman.Skripsi S1 Jurusan Agribisnis Fakultas Pertanian Universitas Sebelas Maret Surakarta

Nicholson, W. 1995. Mikroekonomi Intermediate dan Aplikasinya. Terjemahan dari Intermediate Microeconomics, oleh Agus Maulana. Jakarta : Binarupa Aksara

Simanjuntak, R. 2013. Risiko Produksi Ayam Ras Pedaging Pada Peternakan di Soekartawi. 2006. Agribisnis Teori dan Aplikasi. Jakarta : Rajawali Press

Sofyan, A. 2004. Manajemen Produksi dan Operasi. Jakarta : Lembaga Fakultas Sunaryo, T. 2009. Manajemen Risiko Finansial. Salemba Empat, Jakarta

Suratiyah, K. 2015. Ilmu Usahatani. Jakarta : Penebar Swadaya

330 | Rio Andhika; Nuning Setyowati; Rr. Aulia Qonita; Analisa Resiko Usaha.. 